\title{
Breeding Spring Soft Wheat for Productivity, Grain Quality, and Resistance to Adverse External Factors in Nothern Kazakhstan
}

\author{
Adylkhan Temirhanovich Babkenov ${ }^{1 *}$, Sandukash Amantaevna Babkenova², \\ Kenzhe Kozhakhmetovich Abdullayev³, Yelzhas Konspekovich Kairzhanov ${ }^{4}$
}

1 LLP "Scientific Production Center of Grain Farming named after A.I. Barayev", Barayev street, 15, Shortandy district, Akmola province, 021601, Republic of Kazakhstan

* Correspondng author's e-mail: adylkhan.babkenov@bk.ru

\begin{abstract}
Spring wheat is the main export crop in Kazakhstan. The main share of the grain sold on the world market is the grain of spring wheat grown in Northern Kazakhstan, where the acreage used for this crop reaches $85 \%$, which is about $10 \mathrm{mln}$ ha. Moisture deficiency is the main limiting factor in increasing the yield of spring wheat; in this region, the average annual precipitation is $320-350 \mathrm{~mm}$. Droughts of varying intensity have periodically occurred 2-3 times within the previous five years. Therefore, the yield variability is high and reaches $30 \%$ or more. Another reason for the low yield is the occurrence of wheat diseases. Brown rust and Septoria blight are the most common diseases in the region. Upon the joint manifestation of these diseases, the loss of grain yield may reach $30-40 \%$. The research was aimed at creating a drought-resistant, productive, high-quality variety of spring wheat adapted to changes in the environmental conditions. The method of studying has been generally adopted in breeding and genetic studies. In the competitive grade testing, 40 promising lines of spring soft wheat were studied. Line 371/06 had an average yield of $2.54 \mathrm{t} / \mathrm{ha}$, which was higher by $0.48 \mathrm{t} / \mathrm{ha}$ than in the standard, and ripened at this level. Over the three years of study, this line has significantly exceeded the Astana variety in terms of the yield. Line 371/06, which has $\operatorname{Lr} 37 / \mathrm{Sr} 38$ genes in its genotype, is characterized by group resistance to brown and stem rust. The content of protein in this line amounted on average to $15.22 \%$, which was by $1.38 \%$ higher than in the standard Astana variety. By the gluten content, the excess over the standard reached $2.8 \%$. Over the three years of studying the 40 spring wheat lines, line 371/06 has been chosen, which is high-yielding, resistant to droughts, leaf and stem rust, and is of high grain quality. In 2018, line 371/06 was sent for state grade testing under the name of Taymas.
\end{abstract}

Keywords: spring soft wheat, breeding, variety, productivity, grain quality, brown rust.

\section{INTRODUCTION}

Spring soft wheat is the main export crop in Kazakhstan. The country ranks eighth in the world in terms of grain export. With that, the share of Kazakh grain in the world market of wheat is $2.3 \%$. In $2019,19.1 \mathrm{mln} \mathrm{t}$ of grain were harvested with an average yield of 1.26 $\mathrm{t} / \mathrm{ha}$. According to experts, in the 2019-2020 marketing year, it is planned to export about 4-5 mln t of grain [Ministry of Agriculture of the Republic of Kazakhstan, n.d.]. The main share of grain sold on the world market is the grain of spring wheat grown in Northern Kazakhstan, where the acreage used for this crop reaches $85 \%$, which is about $10 \mathrm{mln}$ ha [Urazaliev, 2013].

The sharp continental and arid climate of Northern Kazakhstan is the main reason for low productivity. Moisture deficiency is the main limiting factor in increasing the yield of spring wheat; in this region, the average annual precipitation is $320-350 \mathrm{~mm}$. Some of the main stressors in the region are the arid conditions in the critical phases of plant growth and development. In Northern Kazakhstan, droughts of varying intensity have periodically occurred 2-3 times within the previous five years. Therefore, the yield variability is high, and depending on the predecessor and background, it reaches $30 \%$ or more [Suleimenov \& 
Akshalov, 2011; Babkenov, 2017]. For instance, in the dry year 2010, the average wheat yield was only $0.9 \mathrm{t} / \mathrm{ha}$. Another reason for the low yield is the occurrence of wheat diseases. Brown rust and Septoria blight are the most common diseases in the region. Upon the joint manifestation of these diseases, the loss of grain yield may reach 30 $40 \%$ [Kokhmetova et al., 2016; Babkenova et al., 2017; Koyshybaev, 2018].

The quality of Kazakhstan wheat grain has recently deteriorated. According to the Ministry of Agriculture of the Republic of Kazakhstan, over the past three years, $64.7 \%$ of wheat grain with the gluten content of $23.0 \%$ have been obtained, whereas, the usual share of such grain has been $80-90 \%$ [Ministry of Agriculture of the Republic of Kazakhstan, n.d.]. There are several reasons to the current situation with grain, which together have resulted in a decrease in the commercial quality of edible wheat: temperature changes, pests, and diseases during the vegetation season, which reduce the amount and quality of gluten in the grain and deteriorate the quality of protein substances [Utebayev et al., 2016; Utebayev et al., 2019].

Thus, in the conditions of increased climate aridity, increasing gross production can be achieved by increasing the yield per unit area. The contribution of breeding in increasing the yield of the main crops over the past decades is estimated at $30-70 \%$, and given the possible climate changes, the role of breeding will continue to grow [Morgounov et al., 2014]. Therefore, it is necessary to create drought-resistant, productive, high-quality varieties of spring wheat adapted to changes in the environmental conditions.

\section{MATERIALS AND METHODS}

In 2016-2018, 40 promising lines of spring soft wheat were studied. In 2016, the meteorological conditions of the vegetation period of spring wheat were characterized as humid, the hydrothermal index (HTI) was 1.3, in 2017 - as arid $(\mathrm{HTI}=0.4)$, and in $2018-$ as humid $(\mathrm{HTI}=1.3)$.

To study the lines by the set of economically valuable traits, spring soft wheat was sown at the competitive grade-testing nursery four times; the plot area was $25 \mathrm{~m}^{2}$. Sowing was performed with the use of an SSFK-7 seeder at the optimum time (May 20-25), and harvesting was performed with the use of a
Wintersteiger Classic plot combine harvester. During the plants' vegetation period, phenological observations were performed, and resistance to drought, diseases, and drowning was determined following the method of the N.I. Vavilov All-Russian Institute of Plant Genetic Resources (VIR) [Merezhko et al., 1999]. The wheat samples' resistance to leaf and stem rust was determined in the conditions of artificial inoculation. Nurseries of brown and stem rust were laid according to the methodology of crops state grade testing [Metodika gosudarstvennogo sortoispytaniya selskokhozyaistvennykh kultur, 2002]. The content of protein in the studied samples was determined on an IR Analyzer following AACC 39-25.01. The content of gluten and its quality were determined according to ISO 7495, 1990 on an IR Analyzer. Molecular genotyping was performed at the Institute of Plant Biology and Biotechnology (Almaty). To identify the carriers of resistance genes, the polymerase chain reaction (PCR) method was used with primers flanking the diagnostic markers of the genes. The obtained data were statistically processed according to the programs of biometric-and-genetic analysis in crop production and breeding - Agros 2.11.

\section{RESULTS}

In the competitive variety testing, 40 promising lines of spring soft wheat were studied. Over the three years, the average yield of standard Astana variety had been $2.06 \mathrm{t} / \mathrm{ha}$, and this variety had ripened in 94 days (Table 1). On average over the three years, line 391/05 had exceeded the yield of the standard Astana variety by $0.04 \mathrm{t} / \mathrm{ha}$ and had ripened one day later than the standard. According to the results of the mathematical processing of the yield data, this line significantly exceeded the standard in terms of the yield in 2016. Line $371 / 06$ had an average yield of $2.54 \mathrm{t} / \mathrm{ha}$, which was higher by $0.48 \mathrm{t} / \mathrm{ha}$ than in the standard and ripened at this level. Over the three years of study, this line significantly exceeded the Astana variety in terms of the yield.

Line 434/05 had ripened two days later than standard variety Astana. In 2016-2018, the yield of this line had been significantly higher than that of the standard; the excess over the standard over the three years had been $0.32 \mathrm{t} / \mathrm{ha}$. 
Line 393/05 had ripened in 96 days and had formed the average yield of $2.55 \mathrm{t} / \mathrm{ha}$, which had been by $0.49 \mathrm{t} / \mathrm{ha}$ higher than that of the standard. A veracious excess in the yield had been observed in 2016 and 2018.

As a result of the phytopathological assessment of the 40 lines on the background of artificial inoculation, the following resistant to brown rust samples were identified: 177/07 (10R), 284/12 (10R), 371/06 (5R), and 245/10 (10R); to stem rust: 245/06-4, 169/10, 177/07, and 371/06. According to the molecular screening of wheat lines using Iag95 molecular marker, a complex of $\mathrm{Lr} 26 / \mathrm{Sr} 31 / \mathrm{Yr}$ 9/Pm8 resistance genes was identified in line 284/12. With the use of the CAPS marker URIC/LN2, $\mathrm{Lr} 37 / \mathrm{Sr} 38 / \mathrm{Yr} 17$ genes were identified in soft wheat line 371/06.

By the set of economically valuable traits, line 371/06 was chosen, which featured high yield and resistance to drought and brown and stem rust. This line is characterized by high indicators of grain quality.

The test weight of grain is an important quality indicator that has been used since the ancient times for determining the milling qualities of the grain. For the studied line 371/06, this value ranged between 769 and $809 \mathrm{~g} / 1$ and averaged $785 \mathrm{~g} / 1$ (Table 2). The highest level of the test weight $(809 \mathrm{~g} / \mathrm{l})$ was noted in the arid year 2017. The lowest value $(769 \mathrm{~g} / \mathrm{l})$ was observed in the humid year 2016.

Vitreousness characterizes the structure of the endosperm, indicating its starch or protein qualities. The vitreousness of line 371/06 ranged between 48 and $61 \%$ and averaged $54 \%$. The highest value (61\%) was observed in the humid year 2018. The vitreousness of strong wheat should be at least $60 \%$. In 2016 and 2017, this value was below this classification norm.

One of the main criteria that determine the quality of wheat grain is the content of protein. In line $371 / 06$, this value ranged between 14.01 and $16.58 \%$, and averaged to $15.22 \%$. The highest value $(16.58 \%)$ was noted in the dry year 2017. In the standard Astana variety, the average protein content was $13.84 \%$, which was lower by $1.38 \%$ than in line 371/06.

The content and quality of gluten determine the baking quality of wheat and depend on the ratio of the content of complex protein substances - glutenins and gliadins. According to the State Standard (GOST-9353-90), strong wheat varieties are characterized by the gluten content of more than $28 \%$, and their quality should correspond to group I (45-75 Units of Gluten Deformation Meter), the gluten content in the

Table 1. The vegetation period and the yield of the best lines in competitive variety testing

\begin{tabular}{|c|c|c|c|c|c|c|}
\hline \multirow{2}{*}{ Variety, line } & \multirow{2}{*}{ Vegetation period, days } & \multicolumn{4}{|c|}{ Yield by year, $\mathrm{t} / \mathrm{ha}$} & \multirow{2}{*}{$\begin{array}{c}\text { Deviation from the } \\
\text { standard, } \pm \mathrm{t} / \mathrm{ha}\end{array}$} \\
\cline { 3 - 6 } & & 2016 & 2017 & 2018 & Average & 0.0 \\
\hline Astana & 94 & 2.30 & 1.59 & 2.30 & 2.06 & +0.48 \\
\hline $371 / 06$ & 94 & 3.09 & 1.82 & 2.72 & 2.54 & +0.04 \\
\hline $391 / 05$ & 95 & 2.58 & 1.46 & 2.27 & 2.10 & +0.32 \\
\hline $434 / 05$ & 96 & 2.75 & 1.79 & 2.59 & 2.38 & +0.49 \\
\hline $393 / 05$ & 96 & 3.18 & 1.58 & 2.90 & 2.55 & \\
\hline & $\mathrm{LSD}_{05}$ & 2.8 & 2.0 & 2.9 & & \\
\hline
\end{tabular}

Table 2. The results of assessing the grain quality of line $371 / 06$

\begin{tabular}{|c|c|c|c|c|c|c|}
\hline \multirow[b]{2}{*}{ Variety, line } & \multirow[b]{2}{*}{ Year } & \multirow[b]{2}{*}{ Test weight, g/l } & \multirow[b]{2}{*}{ Vitreousness, \% } & \multirow[b]{2}{*}{ Protein, \% } & \multicolumn{2}{|c|}{ Gluten } \\
\hline & & & & & $\%$ & $\begin{array}{c}\text { Units of gluten } \\
\text { deformation meter }\end{array}$ \\
\hline \multirow{3}{*}{ Astana } & 2016 & 771 & 46 & 13.73 & 30.8 & 85 \\
\hline & 2017 & 822 & 52 & 15.55 & 34.2 & 80 \\
\hline & 2018 & 786 & 60 & 12.23 & 25.3 & 63 \\
\hline \multicolumn{2}{|c|}{ Average } & 793 & 53 & 13,84 & 30.1 & 76 \\
\hline \multirow{3}{*}{$371 / 06$} & 2016 & 769 & 53 & 15.08 & 33.1 & 86 \\
\hline & 2017 & 809 & 48 & 16.58 & 35.9 & 77 \\
\hline & 2018 & 776 & 61 & 14.01 & 29.8 & 78 \\
\hline \multicolumn{2}{|c|}{ Average } & 785 & 54 & 15.22 & 32.9 & 80 \\
\hline
\end{tabular}


valuable varieties is $23-28 \%$, and the quality of gluten should be of group I and II.

The content of gluten in the studied line $371 / 06$ ranged from 29.8 to $35.9 \%$, and the average value was $32.9 \%$. High gluten content of $35.9 \%$ was formed in the arid year 2017 . The gluten quality in line 371/06 ranged from 77 to 86 Units of Gluten Deformation Meter, and averaged to 80 Units of Gluten Deformation Meter, which corresponded to group II.

\section{DISCUSSION}

Among the studied 40 promising lines of spring soft wheat, five samples were selected that exceeded the Astana standard by the yield on average for the three years of study. Lines 371/06 and 434/05 had consistently exceeded the standard Astana variety in terms of the yield over the three years of the study; this excess was veraciously higher, which was confirmed by the results of mathematical processing.

The weather conditions in 2017 were arid. In this year, lines 371/06 and 434/05 had significantly higher yield than the yield of the standard and therefore were characterized as drought-resistant. According to the analysis of the structure of the main productivity elements, a significant excess of line 371/06 in terms of the yield rate over the Astana standard was explained by higher number of grains per ear -31.3 , grain weight per ear $1.2 \mathrm{~g}$, and the weight of 1,000 grains $-38.5 \mathrm{~g}$; for lines $434 / 05$ - by higher weight of 1,000 grains $(38.6 \mathrm{~g})$. In the standard Astana variety, these values were as follows: the number of grains per ear was 28.0, the weight of grains from an ear was $1.0 \mathrm{~g}$, and the weight of 1,000 grains was $36.2 \mathrm{~g}$.

The weather conditions in Northern Kazakhstan are characterized by a short frost-free period (90-100 days) during the spring wheat vegetation period. In this regard, it is necessary to create more early ripening varieties that would ripen in 90-95 days. Line 371/06 ripened at the level of the standard, while line 434/05 ripened two days later, therefore, the first line was chosen for further study.

By the results of the phytopathological assessment and molecular testing, line 284/12 featured resistance to leaf rust due to the presence of the Lr26 gene. Line 371/06, which had Lr37/Sr38 genes in its genotype, was characterized by group resistance to brown and stem rust.
By the main indicators of grain quality, line 371/06 featured high stability. By the test weight of the grain, line 371/06 had steadily formed high rates of not lower than $750 \mathrm{~g} / 1$, which had corresponded to class I over all the years of the study. Vitreousness of this line had been significantly changing over the years, and in some years fell below $60 \%$, i.e., this indicator was not sustainable. The average protein content in line $371 / 06$ over the three years had been higher than in the Astana standard and had been characterized by stability over the years. The content of gluten in this line had amounted on average to $32.9 \%$, which had been by $2.8 \%$ higher than in the standard Astana variety. By this indicator of grain quality, line 371/06 had stably formed high gluten content over the three years of study. By the quality of gluten, line 371/06 belonged to the second group.

The arid 2017 strongly influenced the grain quality value. For instance, high values were noted in the test weight of grain, the content of protein and gluten, and the lowest value was noted in grain vitreousness. By the three indicators of grain quality (test weight of grain, the content of protein and gluten), this line had consistently formed high quality over the three years of the study. On average over three years of the study, this line had exceeded the standard Astana grade in terms of the content of protein and gluten.

\section{CONCLUSION}

After the three years of studying 40 spring wheat lines, line 371/06 has been chosen, which is high-yielding, resistant to droughts, leaf and stem rust, and is of high grain quality. In 2018, line 371/06 was sent for state grade testing under the name of Taymas.

\section{REFERENCES}

1. Babkenov A.T., Kairzhanov Y.K., Mussynov K.M., Bazilova D.S., Zaitseva O.I. 2017. The productivity of spring soft wheat cultivars grown in Northern Kazakhstan. Ecology, Environment and Conservation, 23, 2, 786-794.

2. Babkenova S.A., Babkenov A.T., Kolomiets T.M., Skolotneva E.S., Divashuk M.G. 2017. Molecular genetic tagging of wheat varieties genes resistant to septoria tritici in Northern Kazakhstan. International Journal of Green Pharmacy, 11, 3, 430-437. 
3. Kokhmetova A., Madenova A., Kampitova G., Urazaliev R., Yessimbekova M., Morgounov A., Purnhauser L. 2016. Identification of leaf rust resistance genes in wheat cultivars produced in Kazakhstan.Cereal Research Communications, 44, 2 , 240-250.

4. Koyshybaev M. 2018. Bolezni pshenitsy [Wheat diseases]. Ankara, 365.

5. Merezhko A.F., Udachin R.A., Zuev E.V., Fila-tenko A.A., Serbin A.A., Lyapunova O.A., Kosov V.Yu., Kurkiev UK., Okhotnikova T.V., Navruzbekov N.A., Boguslavskii R.L., Abdullaeva A.K., Chikida N.N., Mitrofanova O.P., Potokina S.A. 1999. Popolnenie, sokhranenie v zhivom vide i izuchenie mirovoi kollektsii pshenitsy, egilopsa i tritikale [Replenishment, maintenance in live condition, and studying the world's collection of wheat, goatgrass, and triticale]. Methodical Guidelines. SPb, 81.

6. Metodika gosudarstvennogo sortoispytaniya selskokhozyaistvennykh kultur [The methodology of crops state grade testing]. 2002. Almaty, 270-272.

7. Ministry of Agriculture of the Republic of Kazakhstan. Available at: https://moa.gov.kz/ru/post/555

8. Morgounov A., Abugalieva A., Martynov S. 2014. Effect of climate change and variety on long-term variation of grain yield and quality in winter wheat in Kazakhstan. Cereal Research Communications,
$42,1,163-172$.

9. Suleimenov M.K., Akshalov K.A. 2011. Tekhnologiya vozdelyvaniya i urozhainost yarovoi pshenitsy v Severnom Kazakhstane v zavisimosti ot mesta $\mathrm{v}$ sevooborote [The technology of cultivation and the yield rate of spring wheat in Northern Kazakhstan, depending on the position in crop rotation]. Siberian Bulletin of Agricultural Science, 11-12(223), 98-104.

10. Urazaliev R.A. 2013. Sostoyanie, problemy i puti ikh resheniya $\mathrm{v}$ semenovodstve selskokhozyaistvennykh kultur [State, problems and ways of their resolution in crops seed production]. Bulletin of Agricultural Science of Kazakhstan.1, 3-5.

11. Utebayev M., Dashkevich S., Babkenov A., Shtefan G., Bayahmetova S., Kaskarbayev Z., Fahrudenova I., Sharipova B., Shavrukov Y. 2016. Application of gliadin polymorphism for pedigree analysis in common wheat (Triticum aestivum L.) from Northern Kazakhstan.Acta Physiologiae Plantarum, 38, 8, 204.

12. Utebayev, M., Dashkevich, S., Kunanbayev, K., Bome, N., Sharipova, B., Shavrukov, Y. 2019. Genetic polymorphism of glutenin subunits with high molecular weight and their role in grain and dough qualities of spring bread wheat (Triticum aestivum L.) from Northern Kazakhstan. Acta Physiologiae Plantarum, 41(5), 71. 